University of Wollongong

Research Online

Faculty of Engineering - Papers (Archive)

Faculty of Engineering and Information

Sciences

$1-1-2008$

\title{
On the decomposition of Martensite during bake hardening of thermomechanically processed transformation-induced plasticity steels
}

E V. Pereloma

University of Wollongong, elenap@uow.edu.au

M.K Miller

Oak Ridge National Laboratory

Ilana B. Timokhina

Deakin University, Ilana.Timokhina@eng.monash.edu.au

Follow this and additional works at: https://ro.uow.edu.au/engpapers

Part of the Engineering Commons

https://ro.uow.edu.au/engpapers/3300

\section{Recommended Citation}

Pereloma, E V.; Miller, M.K; and Timokhina, Ilana B.: On the decomposition of Martensite during bake hardening of thermomechanically processed transformation-induced plasticity steels 2008, 3210-3216. https://ro.uow.edu.au/engpapers/3300 


\title{
On the Decomposition of Martensite during Bake Hardening of Thermomechanically Processed Transformation-Induced Plasticity Steels
}

\author{
E.V. PERELOMA, M.K. MILLER, and I.B. TIMOKHINA
}

Thermomechanically processed (TMP) CMnSi transformation-induced plasticity (TRIP) steels with and without additions of $\mathrm{Nb}, \mathrm{Mo}$, or $\mathrm{Al}$ were subjected to prestraining and bake hardening. Atom probe tomography (APT) revealed the presence of fine C-rich clusters in the martensite of all studied steels after the thermomechanical processing. After bake hardening, the formation of iron carbides, containing from 25 to 90 at. pct C, was observed. The evolution of iron carbide compositions was independent of steel composition and was a function of carbide size.

DOI: $10.1007 / \mathrm{s} 11661-008-9663-6$

(C) The Minerals, Metals \& Materials Society and ASM International 2008

\section{INTRODUCTION}

FOR decades, the tempering of martensite has attracted the attention of scientists and engineers from both fundamental and applied perspectives. As a result of tempering, carbides precipitate in hard, brittle martensite that is supersaturated in carbon, leading to improved ductility and fracture toughness. ${ }^{[1-6]}$ It is well accepted that there are four stages of tempering of ferrous martensite: (1) formation of transition carbide, presumably $\varepsilon$-carbide, $\mathrm{Fe}_{2.4} \mathrm{C}$, or $\eta$-carbide, $\mathrm{Fe}_{2} \mathrm{C}$; (2) decomposition of retained austenite into ferrite and cementite; (3) replacement of transition carbide by cementite, $\mathrm{Fe}_{3} \mathrm{C}$; and (4) secondary hardening manifested by the development of alloy carbides in alloy steels. ${ }^{[1-6]}$ However, prior to tempering of martensite, room-temperature aging or autotempering of martensite formed at high temperatures on quenching takes place. ${ }^{[3,4,7-10]}$ This process is associated with carbon segregation to dislocations and twin boundaries, to and from retained austenite films, the formation of a periodic tweed structure consisting of carbon modulations in Ni-containing martensites, and carbon clustering before the precipitation of iron-carbide. ${ }^{[7-11]}$ Several experimental techniques, such as electrical resistivity measurements, X-ray diffraction (XRD), transmission electron microscopy, Mössbauer spectroscopy, and atom probe field ion microscopy, have been used to understand the mechanisms and stages of aging and

E.V. PERELOMA, Professor of Physical Metallurgy and Director of the BlueScope Steel Metallurgy Centre, is with the School of Mechanical, Materials and Mechatronics Engineering, University of Wollongong, NSW 2522, Australia. Contact e-mail: elenap@uow. edu.au M.K. MILLER, Distingueshed R\&D Staff, is with the Materials Science and Technology Division, Oak Ridge National Laboratory, Oak Ridge, TN 37831-6136. I.B. TIMOKHINA, Research Academic, is with the Centre for Material and Fibre Innovation, Faculty of Science and Technology, Deakin University, Geelong, Victoria, Australia, 3217.

Manuscript submitted March 16, 2008.

Article published online October 21, 2008 tempering in low- and high-carbon martensitic steels. Previous atom probe studies of martensite decomposition have used atom probe field ion microscopes, which have a severe limitation on the volume of material analyzed. ${ }^{[9-17]}$ Development in recent years of the latest generation of atom probes, namely, the local electrode atom probe, now allows for much faster data gathering from much larger volumes than was possible 5 to 7 years ago. ${ }^{[18,19]}$ This development results in the direct determination of chemical composition, shape, and distribution of fine microstructural features present in the material, even in low densities, such as nanoscale precipitates, clusters, and other solute segregations. The aim of this work is to gain a more detailed insight into martensite decomposition that resulted from the bake hardening of thermomechanically processed (TMP) transformation-induced plasticity (TRIP) steels with and without additions of $\mathrm{Nb}, \mathrm{Mo}$, and $\mathrm{Al}$. Contrary to the majority of previous studies on martensite decomposition, where the microstructure was fully martensitic, here the martensite is a minor phase in the complex multiphase microstructure of TRIP steels.

\section{EXPERIMENTAL}

Four CMnSi TRIP steels with and without additions of $\mathrm{Nb}, \mathrm{Mo}$, or $\mathrm{Al}$ were used in this study. Their compositions are given in Table I. The concentration of main elements $(\mathrm{C}, \mathrm{Mn}$, and $\mathrm{Si})$ in these steels are typical for TMP TRIP steels. ${ }^{[20-22]}$ All studied steels were subjected to laboratory simulation of controlled thermomechanical processing, which is described in detail elsewhere. ${ }^{[23,24]}$ The thermomechanical processing schedule was constructed based on analysis of the continuous cooling transformation data and was aimed to stabilize the retained austenite at room temperature. The steel plates were austenitized at $1250{ }^{\circ} \mathrm{C}$ for 120 seconds and then rolled at $1100{ }^{\circ} \mathrm{C}$ to 25 pct reduction, followed by the second deformation in the nonrecrystallization region 
Table I. Compositions of Studied Steels (Atomic Percent); the Balance is Fe

\begin{tabular}{lcccccrrr}
\hline & \multicolumn{9}{c}{ Element } \\
\cline { 2 - 9 } Steel & $\mathrm{C}$ & $\mathrm{Si}$ & $\mathrm{Mn}$ & $\mathrm{Mo}$ & $\mathrm{Al}$ & $\mathrm{Cu}$ & $\mathrm{Nb}$ \\
\hline $\mathrm{Non}-\mathrm{Nb}$ & 0.95 & 3.01 & 1.54 & - & 0.02 & 0.003 & 0.003 & $\mathrm{P}$ \\
NbMo & 0.96 & 2.88 & 1.49 & 0.114 & 0.02 & 0.017 & 0.021 & 0.044 \\
NbAl & 0.996 & 2.31 & 1.52 & 0.002 & 1.15 & 0.026 & 0.022 & 0.048 \\
NbMoAl & 0.953 & 2.29 & 1.51 & 0.165 & 1.15 & 0.026 & 0.021 & 0.048 \\
\hline
\end{tabular}

Table II. Selected Thermomechanical Processing Parameters

\begin{tabular}{|c|c|c|c|c|}
\hline \multirow[b]{2}{*}{ Steel } & \multicolumn{4}{|c|}{ Parameters } \\
\hline & $T_{N R},{ }^{\circ} \mathrm{C}$ & $T_{A C},{ }^{\circ} \mathrm{C}$ & $T_{C},{ }^{\circ} \mathrm{C}$ & $t_{I H}, \mathrm{~s}$ \\
\hline Non-Nb & 825 & 670 & 450 & 600 \\
\hline NbMo & 875 & 735 & 450 & 1200 \\
\hline $\mathrm{NbAl}$ & 875 & 840 & 500 & 1800 \\
\hline $\mathrm{NbMoAl}$ & 875 & 760 & 470 & 1200 \\
\hline
\end{tabular}

(at $T_{N R}$ ) to 47 pct reduction. After that, the samples were air cooled at $\sim 1 \mathrm{Ks}^{-1}$ to the accelerated cooling start temperatures $\left(T_{A C}\right)$, following by cooling at $50 \mathrm{Ks}^{-1}$ to the coiling temperature $\left(T_{C}\right)$. During isothermal holding $\left(t_{I H}\right)$, the formation of carbide-free bainite took place, and then the samples were water quenched. The selected processing parameters are given in Table II.

Tensile samples were machined from the strip and prestrained to 4 pct in an Instron 4500 servohydraulic tensile testing machine (Instron Pty. Ltd., Melbourne, Australia) with a $100 \mathrm{kN}$ load cell. Bake hardening was carried out at $180{ }^{\circ} \mathrm{C}$ for 30 minutes (1800 seconds). This optimum bake-hardening schedule was chosen based on the highest hardening response of the samples after 1800,3600 , and 10,800 seconds of hold at $150^{\circ} \mathrm{C}$, $180{ }^{\circ} \mathrm{C}$, and $200{ }^{\circ} \mathrm{C}$. The XRD analysis was carried out using a PHILIPS* PW $1130 \quad(40 \mathrm{kV}$ and $25 \mathrm{~mA})$

*PHILIPS is a trademark of Philips Electronic Instruments Corp., Mahwah, NJ.

diffractometer to calculate the volume fraction of retained austenite. The integrated intensities of the $(200)_{\alpha},(211)_{\alpha},(200)_{\gamma}$, and $(220)_{\gamma}$ peaks were used in the direct comparison method. ${ }^{[25]}$

Thin foils were prepared by twin jet electropolishing using a solution of 5 pet perchloric acid in methanol at $-20^{\circ} \mathrm{C}$ and an operating voltage of $50 \mathrm{~V}$. They were examined using a PHILIPS CM20 analytical transmission electron microscope (TEM) operating at $200 \mathrm{kV}$. An Imago local electrode atom probe (LEAP**) was

** LEAP is a trademark of Imago Scientific Instruments Corp., Madison, WI.

used for the analysis of fine features in these steels. The needle-shaped atom probe samples were prepared using a standard two-stage electropolishing procedure. ${ }^{[22]}$ Examination of the samples was performed at $60 \mathrm{~K}$ with a pulse repetition rate of $200 \mathrm{kHz}$ and a pulse fraction of 0.2 . The maximum separation envelope method with a $0.5-\mathrm{nm}$ distance between the carbon atoms and a 0.1-nm grid spacing was used to estimate the extent of solute-enriched regions (radius of gyration) and the local solute concentrations in these regions. ${ }^{[26]}$ Only clusters containing 20 or more atoms were considered in order to eliminate random solute fluctuations in the matrix. The Guinier radii, $r_{G}$, of clusters/ fine carbides were calculated from the radii of gyration $\left(l_{g}\right)$ data with the equation $r_{G}=\sqrt{\frac{5}{3}} l_{g} \cdot{ }^{[26]}$

\section{RESULTS AND DISCUSSION}

The detailed discussion of microstructure-property relationships in these steels after thermomechanical processing and bake hardening has been presented previously. ${ }^{[23,24,27-31]}$ Only the changes in the martensite that resulted from the bake hardening are considered in the present study. Typically, the 8 to 12 pct of martensite present in the microstructure is either in the form of martensite islands in polygonal ferrite/bainite regions, as martensite/retained austenite constituent in granular bainite, or as thin layers between the bainitic ferrite laths of acicular ferrite (Figures 1(a) and (b)). After 4 pct prestraining, some twinned martensite crystals were observed (Figure 1(c)). Their presence could be associated with the strain-induced transformation of high carbon retained austenite. It was shown previously that less chemically and mechanically stable retained austenite transforms to martensite in these steels already after 2 pct straining. ${ }^{[30]}$ The XRD data have confirmed that approximately 2 pct of RA has transformed to martensite after 4 pct prestraining in the studied steels. As TEM studies have shown, fine 

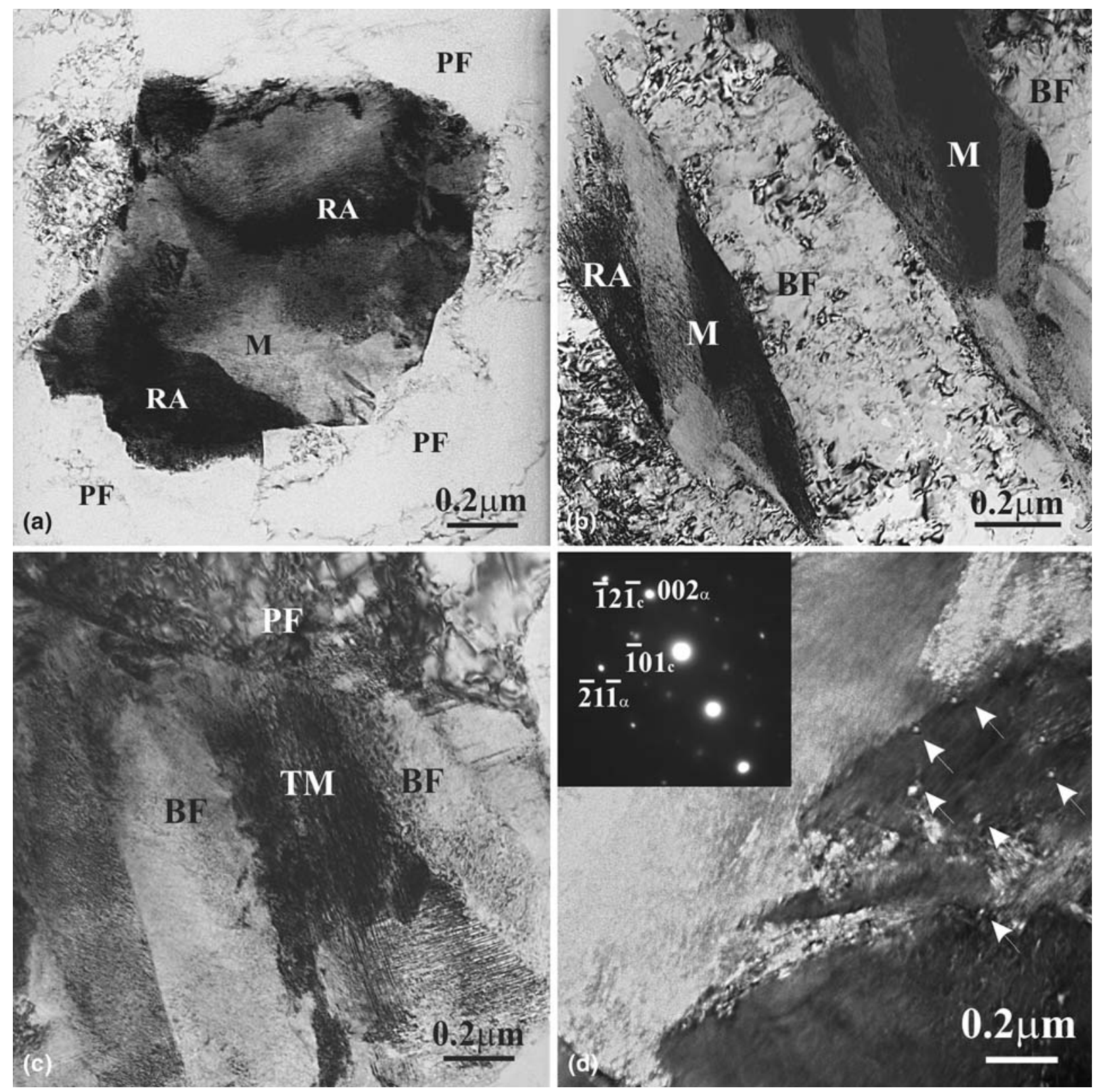

Fig. 1-Representative TEM micrographs of martensite in the steels $(a)$ and $(b)$ after TMP, $(c)$ after prestraining, and $(d)$ after bake hardening. The zone axis in $(\mathrm{d})$ is $[120]_{\alpha} / /[111]_{\mathrm{C}}$, where $\alpha$ denotes the bcc matrix and $\mathrm{C}$ represents carbide. PF-polygonal ferrite, BF-bainitic ferrite, $\mathrm{M}$ - martensite, TM - twinned martensite, and RA - retained austenite. The arrows indicate iron carbides.

iron carbides formed in the martensite after bake hardening (Figure 1(d))

The presence of fine C-rich clusters was detected in the martensite of all the steels studied before bake hardening. Their presence is a manifestation of autotempering either at room temperature or on cooling from the coiling temperature, as the martensite formation temperature in these steels ranges from subzero temperatures to above $200{ }^{\circ} \mathrm{C}$ depending on location, chemical stability, and mechanical stability of retained austenite. ${ }^{[23,24]}$ It was found ${ }^{[9]}$ that the carbon atoms are able to move at $20{ }^{\circ} \mathrm{C}$ through an average distance of $0.2 \mathrm{~nm}$ in a period of 20 seconds with $D_{\mathrm{o}}=0.394 \mathrm{~mm}^{2} \mathrm{~s}^{-1}$ and $Q=80.15 \mathrm{~kJ} \mathrm{~mole}^{-1} \cdot{ }^{[32]}$ Our calculations have also shown the similar value of $0.23 \mathrm{~nm}$. So, it is likely that the redistribution of carbon and formation of clusters at room temperature could contribute to the overall cluster formation process. Clusters that contained between 20 and 100 atoms with sizes ranging from 0.7 to $2.5 \mathrm{~nm}$ were detected in the matrix by the maximum separation method (Figure 2(a), Table III). Here, we define clusters as the nonrandom, preferential segregation of atoms within the volume, in which the crystallographic planes of matrix $(\mathrm{Fe})$ atoms are clearly visible. Contrarily, precipitates exhibit their own, clearly distinguished from the matrix, crystallographic arrangement of atoms into the planes. The finer clusters were pure $\mathrm{C}$, whereas the coarser ones (in addition to $\mathrm{Fe}$ atoms) also contained traces of other elements ( $\mathrm{Si}, \mathrm{Mn}$, $\mathrm{Nb}$, and $\mathrm{Mo}$ ). It should be noted that it is not possible to 


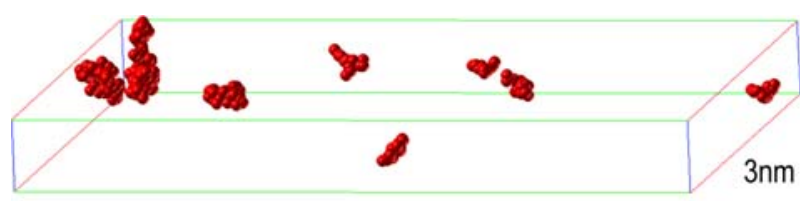

(a)

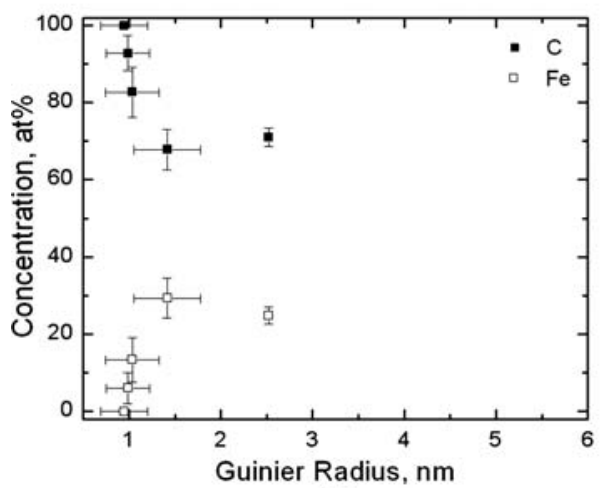

(b)

Fig. 2-(a) C-rich clusters and (b) variation of clusters' compositions with size in martensite of all steels after the TMP. All matrix atoms were removed in (a) by the maximum separation method.

reliably establish from atom probe (or any other) data whether an individual solvent atom on the surface of a particle/cluster belongs to the matrix or the particle. Computer simulations of an iron lattice containing fully coherent, nominally spherical precipitates of different sizes indicate that, as the size of the particle decreases, the concentration of the particle estimated with the envelope method increases due to the aggressive removal of the surface iron atoms. For example, with the use of a 0.1-nm grid spacing, a 60 pct detection efficiency, and excluding all particles at the edge of the analysis volume, the estimated concentrations are 96 pct (with an average of 14 atoms detected), 74 pct (107 atoms), and 56 pct (1632 atoms), for 50 pct solute particles of $0.5,1$, and $2.5 \mathrm{~nm}$ radii, respectively. The estimated Guinier radii were $0.48,0.99$, and $2.5 \mathrm{~nm}$, respectively. The envelope algorithm will only remove solvent atoms from the surface of the particle and not the interior. Thus, the maximum separation envelope method may overestimate the carbon content of the finest clusters by $\sim 25$ to 40 pct in which there is a high proportion of surface to interior atoms. The lowest $\mathrm{C}$ concentration detected in the clusters was $\sim 70$ at. pct C. Even with overestimation of $\mathrm{C}$ concentration, this observation is not in agreement with the suggestion that the clusters should have a $\mathrm{Fe}_{4} \mathrm{C}$ (20 at. pct C) composition. ${ }^{[3]}$ The composition of some clusters was similar to the $\mathrm{FeC}_{8}$ composition. The summary of cluster characterization is given in Table III and Figure 2(b). The standard deviations and error bars given in Tables III and IV and Figures 2(b) and 3(d) are based only on experimental data obtained by the envelope method without taking into account the inherent overestimation of $\mathrm{C}$ content in fine clusters, which is difficult to define exactly due to various shapes of the clusters. As was mentioned previously, this additional error could be 25 to 40 pct for fine clusters. The density of these clusters was of the same order of magnitude in all the steels. However, all clusters had a slightly lower $\mathrm{C}$ content in the steels alloyed with $\mathrm{Al}$ compared to CMnSi (Nb) ones (Table III). No preferential location of clusters, such as along dislocation lines with formation of continuous atmosphere, was detected. However, as dislocation density is extremely high in martensite $\left(\sim 1 \pm 0.2 \times 10^{15} \mathrm{~m}^{-2}\right.$ based on our TEM data) and there is a binding energy between the dislocation core and carbon atoms of $0.75 \mathrm{eV}$, as well as much higher rate of diffusion along the dislocation line than that in the bulk, it is logical to assume that dislocations will be preferential heterogeneous nucleation sites for cluster formation. Due to the high carbon content in martensite ( 2 to 5 at. pct $C^{[24]}$ ) and the high dislocation density, it would be difficult to detect carbon segregation to dislocations $(\sim 1$ to 8 at. pct range) by atom probe tomography (APT) in these alloys, as the difference in concentration of carbon in the atmosphere and in the matrix might not differ significantly.

The change in the martensite after bake hardening is clearly seen in the atom map and isoconcentration surfaces shown in Figure 3. Instead of separated small

Table III. Summary of the Compositions of the Clusters in Martensite after TMP

\begin{tabular}{|c|c|c|c|c|c|}
\hline $\begin{array}{l}\text { Average Cluster } \\
\text { Size, Ions }\end{array}$ & Cluster Characteristics & Non-Nb & NbMo & $\mathrm{NbAl}$ & NbMoAl \\
\hline \multirow[t]{2}{*}{$22 \pm 4(20$ to 27$)$} & $\begin{array}{l}\text { C, at. pct } \\
\text { Fe, at. pct }\end{array}$ & $100 \pm 3$ & $\begin{array}{l}100 \pm 3 \\
-\end{array}$ & not observed & not observed \\
\hline & $r_{g}, \mathrm{~nm}$ & $1.0 \pm 0.3$ & $0.8 \pm 0.1$ & - & - \\
\hline \multirow[t]{3}{*}{$27 \pm 8(21$ to 45$)$} & C, at. pct & $93 \pm 4$ & $92 \pm 5$ & $92 \pm 5$ & $91 \pm 5$ \\
\hline & Fe, at. pct & $6 \pm 4$ & $5 \pm 4$ & $5 \pm 4$ & $7 \pm 3$ \\
\hline & $r_{g}, \mathrm{~nm}$ & $1.0 \pm 0.2$ & $1.1 \pm 0.3$ & $1.0 \pm 0.1$ & $1.1 \pm 0.3$ \\
\hline \multirow[t]{3}{*}{$52 \pm 30(23$ to 76$)$} & C, at. pct & $83 \pm 7$ & $83 \pm 7$ & $81 \pm 6$ & $81 \pm 7$ \\
\hline & $\mathrm{Fe}$, at. pet & $16 \pm 6$ & $10 \pm 5$ & $15 \pm 5$ & $11 \pm 6$ \\
\hline & $r_{g}, \mathrm{~nm}$ & $1.0 \pm 0.3$ & $1.2 \pm 0.3$ & $0.9 \pm 0.2$ & $0.9 \pm 0.1$ \\
\hline \multirow[t]{3}{*}{$96 \pm 62(51$ to 140$)$} & C, at. pct & not observed & $71 \pm 2$ & not observed & $68 \pm 5$ \\
\hline & $\mathrm{Fe}$, at. pet & & $25 \pm 2$ & & $29 \pm 5$ \\
\hline & $\begin{array}{l}r_{g}, \mathrm{~nm} \\
\text { number density, } \mathrm{m}^{-3}\end{array}$ & $\overline{(1.8} \pm 0.2) \times 10^{23}$ & $\begin{array}{l}2.5 \pm 0.1 \\
(6.3 \pm 0.4) \times 10^{23}\end{array}$ & $\overline{(7.7} \pm 0.6) \times 10^{23}$ & $\begin{array}{l}1.4 \pm 0.4 \\
(3.1 \pm 0.3) \times 10^{23}\end{array}$ \\
\hline
\end{tabular}


Table IV. Summary of the Compositions of the Clusters in Martensite after Bake Hardening

Average Cluster

Size, Ions

Cluster Characteristics

Non- $\mathrm{Nb}$

NbMo

$\mathrm{NbAl}$

NbMoAl

$25 \pm 5(20$ to 37$)$

C, at. pct

$100 \pm 3$

$100 \pm 3$

$100 \pm 3$

$100 \pm 3$

Fe, at. pct

$\overline{0.9} \pm 0.2$

$0.9 \pm 0.2$

$52 \pm 42$ (22 to 245$)$

C, at. pct

$94 \pm 4$

$93 \pm 4$

Fe, at. pct

$6 \pm 4$

$r_{g}, \mathrm{~nm} \quad 1.1 \pm 0.3$

$141 \pm 97$ (39 to 337$)$

C, at. pct

$84 \pm 5$

$6 \pm 4$

$15 \pm 5$

$1.1 \pm 0.3$

$\mathrm{Fe}$, at. pct

$81 \pm 5$

$r_{g}, \mathrm{~nm}$

$716 \pm 331(360$ to 1049$)$

C, at. pct

$1.2 \pm 0.5$

$\mathrm{Fe}$, at. pct

$64 \pm 2$

$18 \pm 5$

$1.4 \pm 0.6$

$34 \pm 2$

$r_{g}, \mathrm{~nm}$

$2.9 \pm 0.9$

$61 \pm 2$

$37 \pm 2$

$3328 \pm 470$ (2996 to 3660$) \quad$ C, at. pct

$40 \pm 1$

Fe, at. pct

$56 \pm 1$

$r_{g}, \mathrm{~nm}$

$24921 \pm 23425$

C, at. pct

$4.3 \pm 0.9$

$49 \pm 1$

$47 \pm 1$

$25 \pm 1$

$3.8 \pm 0.7$

(4553 to 64052)

Fe, at. pct

$71 \pm 1$

$r_{g}, \mathrm{~nm}$

$4.7 \pm 0.9$

$-$

$\overline{0.8} \pm 0.1$

$94 \pm 3$

$0.9 \pm 0.1$

number density, $\mathrm{m}^{-3}$

$(2.0 \pm 0.3) \times 10^{23}$

-

$6 \pm 3$

$1.6 \pm 0.1$

not observed

$92 \pm 4$

$7 \pm 4$

$1.1 \pm 0.3$

$82 \pm 4$

$17 \pm 4$

- $\quad 1.7 \pm 0.5$

not observed $\quad 64 \pm 2$

$34 \pm 2$

- $\quad 3.0 \pm 0.7$

not observed $\quad 37 \pm 1$

$58 \pm 1$

$\begin{array}{ll}- & 3.9 \pm 0.1 \\ \text { not observed } & 26 \pm 1\end{array}$

$69 \pm 1$

$4.8 \pm 0.7$

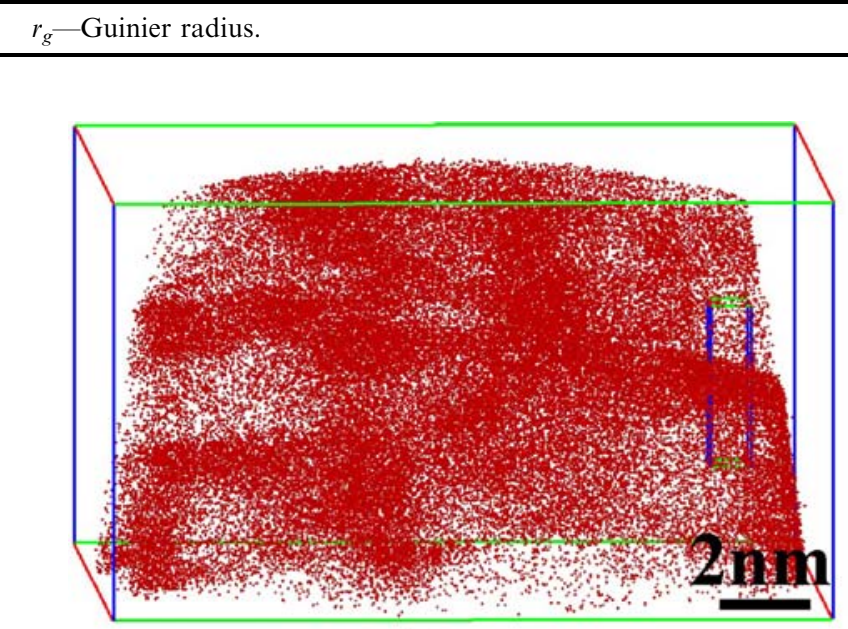

(a)

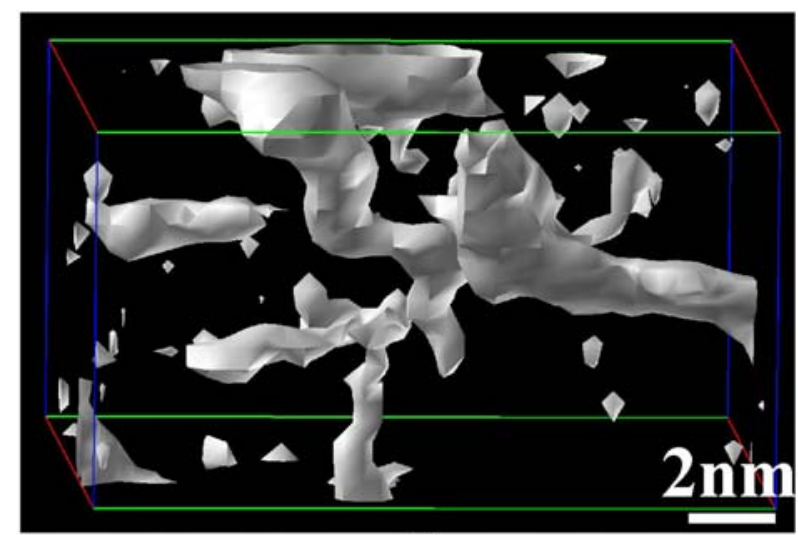

(b)

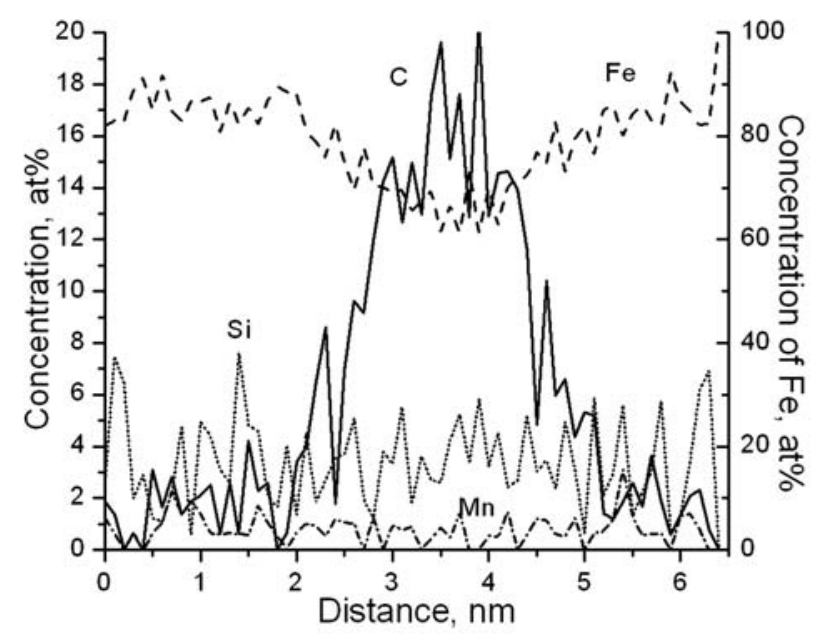

(c)

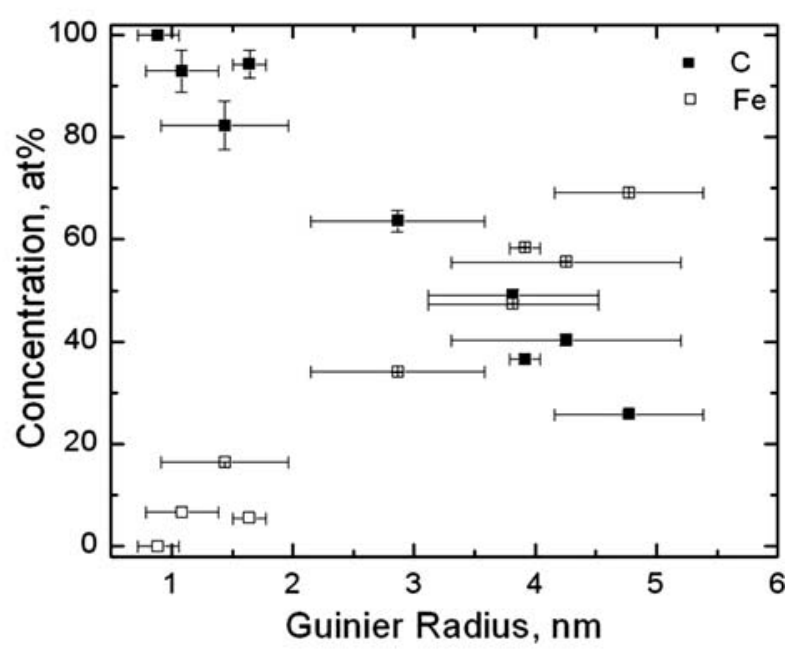

(d)

Fig. 3-Decomposition of martensite after bake hardening: (a) $\mathrm{C}$ atom map, (b) corresponding to 9 at. pct $\mathrm{C}$ iso-concentration surfaces, $(c)$ representative concentration profile taken along the blue (long) line of the selected box in (a), and (d) summary of the effect of the sizes of clusters and particles on their composition in studied steels. 
clusters, which were present in martensite before the heat treatment (Figure 2(a)), a nearly continuous network of coarse carbides has formed in addition to fine individual clusters/particles (Figures 3(a) and (b)). These coarse carbides are partially interconnected and oriented orthogonally to each other. This is an example of the later stage of martensite decomposition, as observed by APT. In many other samples, only separate plates or rods of coarse carbides were detected in addition to fine clusters. ${ }^{[31]}$ The carbon concentration in the matrix, free of visible clusters in the atom map, was reduced from $>2$ to $<0.5$ at. pct, but did not reach the levels of carbon in ferrite, as was reported for the samples after much longer aging times or higher temperatures than used in this study. ${ }^{[10]}$ This indicates that decomposition of martensite has not been fully completed during the bake-hardening treatment. The concentration profiles across the coarse, platelike, or rodlike carbide and cementite particles in all the steels studied show that the concentrations of $\mathrm{Si}$ and $\mathrm{Mn}$ were similar to their matrix levels (Figure 3(c)). This is in agreement with a number of atom probe studies in which no partitioning of $\mathrm{Si}$ and $\mathrm{Mn}$ was observed during early stages of tempering. ${ }^{[14,17]}$

The summary of cluster/fine particle compositions and sizes are given in Table IV and Figure 3(d). After $\mathrm{BH}$, the maximum carbide size increased to $r_{\mathrm{G}}=6 \mathrm{~nm}$. The finer clusters $(\sim 1-\mathrm{nm}$ radius $)$ remained predominantly $\mathrm{C}$ rich, whereas the coarsest ones had a $\mathrm{Fe}_{3} \mathrm{C}$ composition. The composition of intermediate carbides was 40 to 70 at. pct $\mathrm{C}$, with the balance being predominantly $\mathrm{Fe}$. Some of these carbides have the composition close to the one of low-temperature $\mathrm{Fe}_{32} \mathrm{C}_{4}$. This correlates well with the results published by Abe. ${ }^{[33]}$ Most of the particles contained trace levels of $\mathrm{Si}, \mathrm{Mn}$, $\mathrm{Mo}$, and $\mathrm{Nb}$. A similar process of decomposition of martensite during bake hardening at $175^{\circ} \mathrm{C}$ for $30 \mathrm{~min}$ utes was also observed for prestrained to 5 pct intercritically annealed dual-phase and $\mathrm{CMnSi}$ TRIP steels. $^{[34]}$

Although the number density of total clusters and carbides has increased by nearly an order of magnitude compared to the as-TMP condition, the number density of the coarsest carbides $\left(\sim 10^{22} \mathrm{~m}^{-3}\right)$ was an order of magnitude lower than the number density of clusters in the TMP state. It is suggested that a continuous process of cluster formation takes place during bake hardening, whereas some of the pre-existing $\mathrm{C}$-rich clusters in the martensite formed due to autotempering develop into iron carbides, which grow by consuming neighboring clusters. As the diffusivity of carbon in martensite is many orders of magnitude higher than the diffusivity of substitutional elements, at the early stages of nucleation and growth, the $\mathrm{C}$ concentration in the clusters/carbides is high. Despite an overestimation of $\mathrm{C}$ concentration in fine clusters/carbide by the maximum separation distance envelope method, the trend of the reduction of $\mathrm{C}$ content toward the $\mathrm{Fe}_{3} \mathrm{C}$ composition with increase in carbide size was clear. No particles corresponding to $\varepsilon$-carbide composition ( $\sim 30$ at. pct $\mathrm{C})$ were detected, which is in agreement with the data reported by Miller et al. ${ }^{[10]}$

\section{CONCLUSIONS}

The decomposition of martensite in TMP TRIP steels subjected to prestraining and bake hardening was analyzed using APT. It is concluded that formation of carbides during decomposition of martensite is a continuous process starting from the formation of $\mathrm{C}$ clusters as precursors to carbide formation, followed by a compositional evolution and increase in size, which is manifested in a reduction of the $\mathrm{C}: \mathrm{Fe}$ ratio until the equilibrium stoichiometric composition of $\mathrm{Fe}_{3} \mathrm{C}$ is reached.

\section{ACKNOWLEDGMENTS}

This work was partially supported by a University Research Committee Grant, University of Wollongong. The authors thank K.F. Russell, ORNL, and T. Schambron, UOW, for technical assistance. Atom probe research at the Oak Ridge National Laboratory SHaRE User Facility was sponsored by the Scientific User Facilities Division, Basic Energy Sciences, United States Department of Energy.

\section{REFERENCES}

1. G.R. Speich: Trans. TMS-AIME, 1969, vol. 245, pp. 2553-64.

2. G.R. Speich and W.C. Leslie: Metall. Trans., 1972, vol. 3, pp. 1043-54.

3. A.M. Sherman, G.T. Eldis, and M. Cohen: Metall. Trans. A, 1983, vol. 14A, pp. 995-1005.

4. G. Olson and M. Cohen: Metall. Trans. A, 1983, vol. 14A, pp. $1057-65$.

5. H.K.D.H. Bhadeshia and R.W.K. Honeycombe: Steels: Microstructure and Properties, Butterworth-Heinemann, Burlington, MA, 2006, pp. 183-208.

6. G. Krauss: Steels: Processing, Structure, and Performance, ASM INTERNATIONAL, Materials Park, OH, 2005, pp. 327-52.

7. W.K. Choo and R. Kaplow: Acta Metall., 1973, vol. 21, pp. $725-$ 32 .

8. V.I. Izotov and L.M. Utevsky: Phys. Met. Metallogr., 1968, vol. 25 , pp. 86-93.

9. M.K. Miller, P.A. Beaven, and G.D.W. Smith: Metall. Trans. A, 1981, vol. 12A, pp. 1197-04.

10. M.K. Miller, P.A. Beaven, S.S. Brenner, and G.D.W. Smith: Metall. Trans. A, 1983, vol. 14A, pp. 1021-04.

11. K.A. Taylor, L. Chang, G.B. Olson, G.D.W. Smith, M. Cohen, and J.B. Vander Sande: Metall. Trans. A, 1989, vol. 20A, pp. 2717-37.

12. M. Sarikaya, A.K. Jhingan, and G. Thomas: Metall. Trans. A, 1983, vol. 14A, pp. 1121-33.

13. W. Sha, L. Chang, G.D.W. Smith, Liu Cheng, and E.J. Mittemeijer: Surf. Sci., 1992, vol. 266, pp. 416-23.

14. S.S. Babu, K. Hono, and T. Sakurai: Metall. Mater. Trans. A, 1994, vol. 25A, pp. 499-08.

15. R.C. Thomson and M.K. Miller: Appl. Surf. Sci., 1995, vol. 87/88, pp. $185-93$.

16. R.C. Thomson and M.K. Miller: Acta Mater., 1998, vol. 46, pp. 2203-13.

17. R.C. Thomson: Mater. Characterization, 2000, vol. 44, pp. 21933.

18. T.F. Kelly, P.P. Camus, D.J. Larson, L.M. Holzman, and S.S. Bajikar: U.S. Patent Serial No. 08/272204, 1995.

19. M.K. Miller: Microsc. Res. Technol., 2006, vol. 69, pp. 359-65

20. I. Tsukatami, S. Hashimoto, and T. Inoue: ISIJ Int., 1991, vol. 31, pp. $992-1000$ 
21. K.-I. Sugimoto, M. Tsunezawa, T. Hojo, and S. Ikeda: ISIJ Int., 2004, vol. 44, pp. 1608-14.

22. S. Hashimoto, S. Ikeda, K.-I. Sugimoto, and S. Miyaki: ISIJ Int., 2004, vol. 44, pp. 1590-98.

23. I.B. Timokhina, P.D. Hodgson, and E.V. Pereloma: Metall. Mater. Trans. A, 2004, vol. 35A, pp. 2331-41.

24. E.V. Pereloma, I.B. Timokhina, M.K. Miller, and P.D. Hodgson: Acta Mater., 2007, vol. 55, pp. 2587-98.

25. B.D. Cullity: Elements of X-Ray Diffraction, 2nd ed., AddisonWesley Publishing Company, Reading, MA, 1978, p. 555.

26. M.K. Miller: Atom Probe Tomography, Kluwer, Academic/ Plenum Press, New York, NY, 2000, pp. 28-197.

27. I.B. Timokhina, M. Ryan, M.K. Miller, and E.V. Pereloma: Iron and Steel, 2005, vol. 40 (Suppl), pp. 744-48.

28. E.V. Pereloma, I.B. Timokhina, and M.K. Miller: Proc. Int. Conf. New Developments on Metallurgy and Applications of High
Strength Steels, Buenos Aires, Argentina, May 26-28 2008, paper no. 104.

29. E.V. Pereloma, I.B. Timokhina, K.F. Russell, and M.K. Miller: Scripta Mater., 2006, vol. 54, pp. 471-76.

30. I.B. Timokhina, P.D. Hodgson, and E.V. Pereloma: Metall. Mater. Trans. A, 2003, vol. 34A, pp. 2331-41.

31. E.V. Pereloma, K.F. Russell, M.K. Miller, and I.B. Timokhina: Scripta Mater., 2008, vol. 58, pp. 1078-81.

32. A.E. Lord, Jr. and D.N. Beshers: Acta Metall., 1966, vol. 14, pp. 1659-72.

33. H. Abe: Scand. J. Metall., 1984, vol. 13, pp. 226-39.

34. I.B. Timokhina, P.D. Hodgson, S.P. Ringer, R.K. Zheng, and E.V. Pereloma: Proc. Int. Conf. New Developments on Metallurgy and Applications of High Strength Steels, Buenos Aires, Argentina, May 26-28, 2008. 